\title{
LISTINA ZÁKLADNÍCH PRÁV EU JAKO MĚŘÍTKO PRO VNITROSTÁTNÍ LEGISLATIVU?*
}

\author{
JAN GRINC
}

\begin{abstract}
The Charter of Fundamental Rights of the EU as a yardstick for national legislation? The article discusses the possibilities and modes of utilizing the Charter of Fundamental Rights of the EU as a human rights yardstick against which national legislation may be measured, especially in the Czech Republic. It considers the formal and material features of the Charter and comes to a conclusion that because of the close link between the Charter and the rest of EU law, the assessment whether national legislation complies with the Charter is best made as a part of the assessment of the legislation's compatibility with EU law in general. Used separately as a source of human rights, the Charter has little new to offer in comparison with the national and international sources.
\end{abstract}

Keywords: Charter of Fundamental Rights of the EU; legislation; fundamental rights

Klíčová slova: Listina základních práv EU; legislativa; základní práva

DOI: $10.14712 / 23366478.2018 .29$

\section{1. ÚVOD}

Vnitrostátní aplikace Listiny základních práv EU (dále též jen „Listina“) není jen záležitostí moci soudní, popř. výkonné. V úvahu přichází i její aplikace při vnitrostátní tvorbě právních předpisů. Vázanost zákonodárce základními právy je v Evropě dnes již nesporným rysem právních řádů. ${ }^{1}$ Určit konkrétní obsah a rozsah základních práv ale již tak snadné není. Vedle vnitrostátních ústavních katalogů jsou totiž pramenem jejich první úpravy i mezinárodní smlouvy, mezi nimi především minimální společný standard zakotvený v Úmluvě o ochraně lidských práv a základních svobod a jejích dodatkových protokolech (dále jen „Úmluva“). K tomu přistupují základní prá-

* Tento výstup vznikl v rámci projektu Specifického vysokoškolského výzkumu 2017-2019 s názvem „Právní vědomí: pojem, formování, účinky se zvláštním zřetelem k působení Listiny základních práv Evropské unie na právní vědomí v České republice“, č. 260 361, řešeného na Právnické fakultě Univerzity Karlovy.

1 Nesnadné prosazování této teze před druhou světovou válkou dokládá KREJČÍ, J.: Základní práva občanská a rovnost před zákonem. Praha: Moderní stát, 1929, zejm. s. 5-56. Specifickou výjimku dodnes představuje Spojené království. K tomu viz KINDLOVÁ, M.: Ochrana lidských práv ve Spojeném království. In PAVLÍČEK, V. - HOFMANNOVÁ, H. a kol.: Občanská a lidská práva v současné dobè. Praha: Auditorium, 2014, s. 155-187. 
va jako součást práva EU ve formě obecných zásad a později i článků Listiny, jimiž jsou v určitých prípadech vázány i orgány členských států. Každý z těchto pramenů je navíc do značné míry autonomně vykládán příslušnými soudními institucemi, ačkoli lze říci, že na vnitrostátní i unijní výklad základních práv má velký vliv judikatura Evropského soudu pro lidská práva. Zákonodárce musí usilovat o to, aby vyhověl nejvyššímu pro něj závaznému standardu ochrany.

Tento př́íspěvek se zabývá aplikací Listiny ve vnitrostátním zákonodárném procesu jakožto měřítka pro posuzování souladu návrhů zákonů (popř. jiných právních předpisů) se základními právy. Přináší Listina nějakou novou kartu do baličku pramenů základních práv? Je vhodné ji používat jako samostatné dílčí měřítko pro posuzování zákonů, jako součást holistického posuzování souladu návrhů zákonů se základními právy (bez ohledu na jejich pramen), nebo jen v rámci ověřování jejich souladu s právem EU jako takovým? Př́stupy členských států EU se liší. Např́íklad v Nizozemí a Finsku byla zavedena zvláštní procedura pro posuzování souladu návrhů zákonů s Listinou, ${ }^{2}$ zatímco $\mathrm{v}$ jiných státech $\mathrm{k}$ ničemu takovému nedošlo. Zde se však nebudeme zabývat srovnáváním právní úpravy a praxe $\mathrm{v}$ jednotlivých členských státech a omezíme se na výchozí teoretické úvahy o použitelnosti a užitečnosti Listiny ve výše uvedené roli. Tyto úvahy mohou být relevantní pro zodpovězení otázky, v jakých souvislostech má smysl zkoumat aplikaci Listiny ve vnitrostátní normotvorbě, zejména př́padné odkazy na Listinu v důvodových zprávách návrhů právních předpisů, v parlamentních rozpravách a v jiných př́pravných dokumentech vnitrostátního legislativního procesu.

\section{POSTAVENÍ LISTINY V PRÁVU EU, JEJÍ PŮSOBNOST A PROCESNII KONTEXT JEJÍ SOUDNÍ INTERPRETACE A APLIKACE}

Zásadní odlišnost mezi Listinou a ostatními prameny základních práv spočívá ve vztahu mezi unijním a vnitrostátním právem. Vzhledem k principu přednosti práva EU není pro vnitrostátního zákonodárce velký rozdíl mezi Listinou a jinými součástmi práva EU. Vše tvoří limity a požadavky plynoucí z práva EU, které je třeba při vnitrostátní normotvorbě dodržet. Konkrétněji budou ovšem tyto limity a požadavky vyjádřeny spíše v sekundárním právu EU, než v Listině. Oproti tomu ústavní katalogy základních práv mají vyšší právní sílu než běžné zákony a Úmluva není aplikována v kontextu nějakého širšího korpusu práva, neřkuli samostatného právního řádu.

Listina zároveň na rozdíl od ústavních a mezinárodních katalogů není na vnitrostátní úrovni použitelná vždy, nýbrž výhradně pokud členské státy „uplatňují právo Unie“ (čl. 51 odst. 1 Listiny). Podle Vysvětlení k Listině (dále jen „Vysvětlení“)3 to znamená ,jednají-li v oblasti působnosti práva Unie“. V rovině legislativy to jistě bude zahrno-

2 Viz zprávu ze semináře o aplikaci Listiny v národní politice konaného dne 19. února 2016 v Amsterdamu $\mathrm{v}$ rámci nizozemského předsednictví v Radě EU. National policy application of the EU Charter of Fundamental Rights - Presidency seminar report. Dokument Rady EU č. 8927/16, 2016. Dostupné z http://data .consilium.europa.eu/doc/document/ST-8927-2016-INIT/en/pdf.

3 Vysvětlení byla vyhlášena v Úředním věstníku pod č. 2007/C 303/02. Podle čl. 52 odst. 7 Listiny k nim mají soudy Unie a členských států „náležitě přihližět“. 
vat veškeré transpoziční předpisy. Ale co jiné vnitrostátní předpisy nějakým způsobem související s právem EU, např́ílad předpisy zajištující návaznost př́́mo použitelného práva EU na vnitrostátní právo? Rozsah působnosti Listiny ve vnitrostátním kontextu je bezmála deset let po jejím vstupu v platnost stále poměrně nejasný. ${ }^{4} \mathrm{Na}$ základě dosavadní judikatury však patrně lze učinit obecný závěr, že Soudní dvůr EU nepřipouští zcela samostatné uplatnění Listiny na jednání států v působnosti práva EU (nebot' pak by se Listina vztahovala prakticky na veškeré jednání členských států s kompetenčními důsledky pro Komisi a Soudní dvůr), nýbrž její aplikaci podmiňuje existencí konkrétního pravidla práva EU, které dopadá na daný skutkový stav. ${ }^{5}$ Tím se opět dostáváme k významu zejména sekundárního práva EU pro aplikaci Listiny.

Je též zřejmé, že jakékoli posuzování souladu návrhu zákona s Listinou musí začínat zodpovězením otázky, zda návrh zákona spadá do oblasti působnosti práva EU. Nabízí se samozřejmě i použití Listiny též na návrhy právních předpisů, které zjevně nespadají do její vlastní působnosti. Taková praxe by ovšem v legislativním procesu byla nadbytečná a matoucí (vytvářel by se dojem, že dle zákonodárce daná právní úprava spadá do působnosti práva EU). Rozšíření použitelnosti Listiny i na ryze vnitrostátní záležitosti by dále mohlo vyplynout z vnitrostátního práva členského státu (s relevancí pouze pro tento stát). Teoreticky by si mohl vnitrostátní ústavodárce Listinu jako katalog základních práv „vypůjčit“ pro ryze vnitrostátní situace. Musel by ale zároveň autonomně založit její působnost pro takové př́pady. Proto v př́ípadě, že bychom v českém kontextu odpověděli kladně na otázku, zda je Listina základních práv EU (resp. Lisabonská smlouva) mezinárodní smlouvou o lidských právech, a tudíž ve smyslu nálezu Ústavního soudu sp. zn. Pl. ÚS 36/01 součástí ústavního pořádku, ${ }^{6}$ nebude tím bez dalšího rozšířena působnost Listiny.

Význam Listiny pro vnitrostátního zákonodárce je ovlivněn též procesním kontextem její soudní interpretace a aplikace.

V právu EU především neexistuje procesní prostředek obdobný ř́zení o individuálních stížnostech podle Úmluvy nebo vnitrostátní ústavní stížnosti. Přezkum souladu jednání veřejné moci s Listinou tedy nebude tak častý a tak př́imý. Může k němu dojít v př́ípadech, kdy právo EU výjimečně připouští žalobu jednotlivce na neplatnost právního aktu EU. Tyto př́ípady ale zpravidla nejsou bezprostředně relevantní pro vnitrostátní zákonodárství, nebot' jde o přezkum aplikace velmi specifických ustanovení práva EU orgány EU. ${ }^{7}$

4 Nejnověji např. HAMULÁK, O. - MAZÁK, J.: The Charter of Fundamental Rights of the European Union vis-à-vis the Member States. Scope of its Application in the View of the CJEU. Czech Yearbook of International Law, 2017, č. 8, s. 161-172.

5 Tamtéž, s. 170-171.

6 Vzhledem k odlišnému účelu a působnosti Listiny ve srovnání s mezinárodními smlouvami o lidských právech (orgány EU jako primární adresáti, použitelnost jen v mezích působnosti práva EU) se přikláním k záporné odpovědi. Srov. též dosavadní debatu a argumenty, které nastiňuje HAMULÁK, O.: Listina základních práv Evropské unie jako okolí ústavního pořádku České republiky. Acta Iuridica Olomucensia, 2015 , č. 3, s. 7-30.

7 Srov. např. seznam rozhodnutí Soudního dvora EU z roku 2016 zmiňujících Listinu, který je př́lohou publikace Evropské komise 2016 report on the application of the EU Charter of Fundamental Rights. Luxembourg: Publications Office of the European Union, 2017. Dostupné z http://ec.europa.eu/newsroom /document.cfm?doc_id=46000. Z tohoto seznamu vyplývá, že velký počet případů aplikace Listiny spočívá v žalobách na neplatnost proti omezujícím opatřením (mezinárodním sankcím) a v žalobách úredníků 
Rovněž abstraktní kontrola „ústavnosti“ (souladu se Smlouvami) má v EU poněkud jiný charakter než ve vnitrostátním kontextu, kde může sloužit typicky opozici, menšině nebo hlavě státu $\mathrm{v}$ př́padech, kdy zákon, který získal podporu parlamentní většiny, vzbuzuje pochybnosti z hlediska souladu s ústavou. V právu EU může žalobu na neplatnost právního aktu podat obecně jen Komise, Rada, Evropský parlament a členský stát. Vzhledem $\mathrm{k}$ tomu, že evropský legislativní proces v právní úpravě i praxi směřuje ke shodě tří uvedených institucí, je zřejmé, že jen výjimečně bude některá z nich zpochybňovat obsahovou stránku (dokonce soulad se základními právy) právního aktu, na jehož přijetí se sama podílela. Protože menšina členů Evropského parlamentu žalobní právo nemá, může hlas ,,menšiny“ zaznít prakticky jen v žalobě členského státu. Ten zpravidla nebude v prvé řadě namítat rozpor se základními právy, ale spíše bude hledat argumenty $\mathrm{k}$ ochraně své vnitrostátní politiky či právní úpravy před zásahem v podobě príijatého právního aktu EU. I v tomto druhu ř́zení je tedy argumentace rozporem se základními právy možná, avšak na rozdíl od vnitrostátních systémů abstraktní kontroly ústavnosti patrně nebude dominantní. Počet těchto řízení je navíc poměrně nízký.

Prostor pro aplikaci Listiny nalezneme $\mathrm{v}$ řízení pro nesplnění povinnosti členským státem. Většina př́padů nesplnění povinností členským státem ale nespočívá v porušování základních práv a Komise v těchto rízeních Listinou neargumentuje. ${ }^{8}$

Konečně je zde řízení o předběžné otázce, v němž Soudní dvůr EU může použít Listinu při výkladu konkrétního ustanovení sekundárního (či vzácněji primárního) práva. Výsledkem je tedy výklad konkrétního pravidla práva EU ve světle Listiny. ${ }^{9}$ Takový výklad může být samozřejmě nutné zohlednit i v legislativní činnosti (např. pozměnit transpoziční předpis) a může mít i obecnější přesah (např. pro výklad obdobných ustanovení $v$ jiných předpisech práva $\mathrm{EU}$, nebo při nahrazení př́íslušného předpisu EU novým, který bez podstatných změn převezme vyložené ustanovení). Zejména v těchto situacích bude pro zákonodárce Listina zásadní.

Interpretace Listiny vnitrostátními soudy bude pro zákonodárce významná opět především ve spojení s výkladem Listiny Soudním dvorem EU. Naopak k prrípadným dalekosáhlým interpretačním vývodům vnitrostátních soudů činěným bez toho, aby se $\mathrm{k}$ věci vyjádřil Soudní dvůr EU, by měl zákonodárce přistupovat velmi obezřetně.

Z vymezení působnosti Listiny a z procesního kontextu její soudní aplikace tak plyne, že Listina, jakož i její soudní interpretace a aplikace, je úzce svázána s konkrétními předpisy práva EU.

\section{OBSAH A LEGISLATIVNÍ TECHNIKA LISTINY}

Př́nos dalšího katalogu základních práv může spočívat též v novém obsahu či v přesnějších formulacích ve srovnání s katalogy dosavadními.

institucí EU. Pro vnitrostátního zákonodárce může být významná judikatura ve věcech hospodářské soutěže, kde je v žalobách často namítáno porušení procesních práv ze strany Komise.

8 Srov. též ŁAZOWSKI, A.: Decoding a Legal Enigma. The Charter of Fundamental Rights of the European Union and infringement proceedings. ERA Forum, 2013, č. 4, s. 573-587.

9 Pro typickou formulaci výroku rozsudku Soudního dvora EU v tomto řízení s odkazem na Listinu viz C-562/13 Abdida, EU:C:2014:2453. 
Po obsahové stránce je Listina vpravdě eklektickým dokumentem. Zahrnuje práva všech obvykle rozlišovaných kategorií a generací a v zásadě pokrývá evropský mezinárodněprávní standard v oblasti lidských práv. Jak již bylo řečeno, v řadě oblastí dotýkajících se základních práv má EU jen okrajovou kompetenci, takže se Listina bude aplikovat převážně na určité výseče dané problematiky upravené právem EU (např. sociální práva ve vztahu k přeshraničně mobilním osobám, právo nebýt mučen v souvislosti s navracením či vyhošt'ováním osob do třetích zemí aj.). V Listině nalezneme i některá inovativní ustanovení, u nichž však může být sporné, zda do katalogu základních práv vůbec patří a zda ho svou prrítomností poněkud nedevalvují (např. čl. 38 - ochrana spotřebitele).

Po stránce legislativně-technické Listina příliš nevybočuje z obvyklého zpracování katalogů základních práv. Zvláštní je pouze absence podrobnější úpravy mezí jednotlivých základních práv. Tyto meze jsou stanoveny velice zběžně obecným ustanovením čl. 52 odst. 1. Ustanovení o jednotlivých právech pak někdy obsahují rozmělňující formulace, že určité právo se zaručuje v souladu s právem Unie nebo s vnitrostátními předpisy), Vysvětlení pak u řady práv odkazují na podmínky jejich omezení stanovené Úmluvou. ${ }^{10}$ Výkladová ustanovení Listiny (a Vysvětlení) tím výrazně zpochybňují relevanci jazykového vyjádření práv v Listině. Při interpretaci základních práv se samozřejmě nelze omezit jen na jazykový výklad, ale to neznamená, že lze rezignovat na snahu o přesnost a specifičnost jejich formulace, protože v takovém př́ípadě se z jednotlivých ustanovení stávají jen vágní deklarace, jejichž obsah zcela závisí na prováděcích předpisech a soudní interpretaci.

Určité upřednostnění symbolického významu Listiny před snahou o její pečlivé zasazení do unijního, mezinárodního a vnitrostátního právního kontextu, v němž má působit, dokládají i ostatní výkladová ustanovení hlavy VII Listiny a Vysvětlení. Není např́íklad zcela zřejmé, které články Listiny obsahují práva a které obsahují jen zásady s omezenou použitelností podle čl. 52 odst. 5 Listiny. Obecná otázka vztahu Listiny a standardů ochrany v mezinárodním právu a ve vnitrostátním právu členských států je pak řešena enigmatickým čl. 53, který - není-li vykládán doslova jako prolomení principu přednosti práva EU - nedává vodítko, jak řešit případnou kolizi, pokud by z výkladu Listiny (resp. práva EU jako celku) vyplýval nižší standard ochrany základních práv než z jiného pramene. ${ }^{11}$

Obsahově se Listina výrazně překrývá s mezinárodněprávními závazky členských států, a to zčásti formulačně a zčásti prostřednictvím výkladových ustanovení. Podle čl. 52 odst. 3 je smysl a rozsah práv obsažených v Listině, která odpovídají právům zaručeným Úmluvou, stejný jako jim přikládá Úmluva. Podle Vysvětlení je třeba zde zohlednit judikaturu Evropského soudu pro lidská práva, ale i Soudního dvora EU. Jedná se o čl. 2, čl. 4, čl. 5 odst. 1 a 2, čl. 6, čl. 7, čl. 9, čl. 10 odst. 1, čl. 11 odst. 1, čl. 12 odst. 1 , čl. 14 odst. 1 a 3, čl. 17, čl. 19, čl. 21 odst. 1 , čl. 47 odst. 2 a 3, čl. 48 , č. 49 odst. 1 a 2 a čl. 50. Právo EU však může poskytnout širší ochranu, a tak u některých z těchto

10 Srov. jen teoretický rozbor BÜHLER, M.: Einschränkung von Grundrechten nach der Europäischen Grundrechtecharta. Berlin: Duncker \& Humblot, 2005.

11 Srov. např. WIDMANN, A.-M.: Article 53. Undermining the Impact of the Charter of Fundamental Rights. Columbia Journal of European Law, 2012, č. 2, s. 342-358. 
ustanovení dochází Listinou k rozšíření působnosti oproti Úmluvě. Většinou ale nejde o zásadní odchylky. ${ }^{12}$ Zdaleka nejvýznamnější je čl. 47 Listiny, který zakotvuje právo na účinné právní prostředky nápravy před soudem ve všech př́padech porušení práv a svobod zaručených právem Unie a dále právo na spravedlivý proces bez omezení na rozhodování o občanských právech a závazcích a o trestních obviněních (čl. 6 Úmluvy). ${ }^{13} \mathrm{~V}$ některých př́ípadech Listina nepřebírá z Úmluvy ta ustanovení, u nichž se patrně předpokládalo, že nebudou z hlediska kompetencí EU relevantní (napřs. podmínky zbavení osobní svobody v čl. 5 Úmluvy, právo na odvolání v trestních věcech podle čl. 2 Protokolu č. 7 k Úmluvě).

Další ustanovení Listiny pak vycházejí z Evropské sociální charty, popř. Revidované Evropské sociální charty (čl. 14 odst. 1, čl. 15 odst. 1 a 3, čl. 25 až 35), Úmluvy o lidských právech a biomedicíně (čl. 3 odst. 2), Ženevské úmluvy o právním postavení uprchlíků (čl. 18) a Úmluvy o právech dítěte (čl. 24). Většina členských států ratifikovala všechny tyto smlouvy. Některé neratifikovaly Úmluvu o lidských právech a biomedicíně a Revidovanou Evropskou sociální chartu. Česká republika neratifikovala druhou uvedenou smlouvu. Z ní vychází zejména čl. 25 (práva starších osob), čl. 27 (právo pracovníka na informování a na projednání v podniku) a čl. 30 (ochrana v př́ipadě neoprávněného propuštění) Listiny. Čl. 25 lze však považovat spíše za zásadu než za právo a čl. 27 a 30 zaručují uvedená práva pouze za podmínek, které stanoví právo Unie a vnitrostátní právní předpisy. Nejde tedy o zásadní mezeru v ochraně základních práv v České republice, kterou by Listina vyplňovala.

Ačkoli se v jednotlivých státech může lišit postavení uvedených smluv v právním řádu a možnost domáhat se jich před vnitrostátními orgány, z hlediska vnitrostátní legislativní činnosti lze učinit závěr, že ustanovení Listiny takto převzatá z mezinárodních smluv nebo odkazující na ně nepřinášejí nic nového, nebot’ jen opakují stávající mezinárodněprávní závazky. Výjimkou jsou př́ípady, kdy některý členský stát ratifikoval př́slušnou smlouvu s výhradou $\mathrm{k}$ jejím jednotlivým článkům. ${ }^{14} \mathrm{Z}$ Listiny ani z Vysvětlení neplyne, že by se při aplikaci Listiny mělo k těmto výhradám přihlížet. Proto se v rámci působnosti Listiny tyto výhrady nemohou uplatnit. České republiky se ale tento problém netýká.

Většina ostatních ustanovení Listiny (a duplicitně i některá ustanovení odpovídající článkům Evropské sociální charty a Revidované Evropské sociální charty) se v totož-

12 Podrobněji k těmto rozdílům mezi Listinou a Úmluvou BÜHLER, M.: Einschränkung von Grundrechten nach der Europäischen Grundrechtecharta. Berlin: Duncker \& Humblot, 2005, s. 331-349.

13 Čl. 47 Listiny může mít dalekosáhlé, potenciálně až paralyzující důsledky, protože při extenzivní interpretaci jím lze např. eliminovat i racionální kompetenční výluky ve správním soudnictví. Pro ilustraci viz rozsudek Soudního dvora C-403/16 El Hassani, ECLI:EU:C:2017:960.

14 Nejde zdaleka o marginální problém. Živě diskutovanou otázkou výkladu Úmluvy nejen v ČR se v důsledku některých rozhodnutí Evropského soudu pro lidská práva (rozsudek velkého senátu ze dne 10. 2. 2009 ve věci Zolotukhin proti Rusku, č. 14939/07 a rozsudek ze dne 20. 5. 2014 ve věci Lucky Dev proti Švédsku, č. 11828/11) stalo uplatnění zásady ne bis in idem dle čl. 4 Protokolu č. 7 k Úmluvě na souběh soudního a správního trestání (např. v oblasti daňového práva, které je zčásti regulováno i právem EU). Př́slušný protokol však řada smluvních stran včetně např́ílad Německa a Francie ratifikovala s výhradou, že pojem „trestní obvinění“ v něm uvedený se vztahuje pouze na činy soudně trestné podle jejich vnitrostátního práva, čímž se dopadům této judikatury vyhnula. 
ném znění, popř. s dalšími podrobnostmi, nachází též ve Smlouvě o Evropské unii nebo Smlouvě o fungování Evropské unie. Konkrétně je to čl. 8 o ochraně osobních údajů (který se však zcela nepřekrývá s čl. 16 Smlouvy o fungování EU), čl. 12 odst. 2, čl. 15 odst. 2, čl. 21 až 23 a čl. 36 až 46. Často jde o politická práva vůči unijní veřejné moci (např. petiční právo $\mathrm{k}$ Evropskému parlamentu, právo na řádnou správu vůči orgánům, institucím a jiným subjektům Unie), která ani nemohou být předmětem vnitrostátní legislativy. U řady těchto i dalších práv je pak stanoveno, že se zaručují „V souladu s právem Unie“, tedy za podmínek stanovených jinými předpisy práva EU.

Po odečtení všech výše uvedených ustanovení zbývají některé články bez zřetelného předobrazu ve výše uvedených smlouvách, které však formulují práva či zásady jako je ochrana lidské důstojnosti nebo rovnost před zákonem, obsažené v jiných mezinárodněprávních dokumentech, jakož i v ústavách členských států - čl. 1, čl. 3 odst. 1, čl. 5 odst. 3, čl. 13, čl. 16, čl. 20. Z elementárních principů trestního práva vychází čl. 49 odst. 3. Pro Českou republiku není nový ani čl. 10 odst. 2 (právo odmítnout vykonávat vojenskou službu z důvodu svědomí) a čl. 14 odst. 2 (právo na bezplatnou povinnou školní docházku). Respektování svobody a plurality sdělovacích prostředků (čl. 11 odst. 2) český ústavní pořádek výslovně nezakotvuje, jde však o součást svobody projevu a práva na informace.

Zatímco zejména v některých starých členských státech může být vnitrostátní katalog základních práv oproti Listině užší a rovněž možnosti jednotlivců dovolávat se základních práv, která nejsou zakotvena v Úmluvě, mohou být omezené, Česká republika má poměrně široký ústavní katalog základních práv a s výjimkou Revidované Evropské sociální charty bez výhrad ratifikovala všechny mezinárodní smlouvy, z nichž Listina vychází. Proto zde Listina zákonodárci obsahově nepřináší mnoho nového.

\section{ZÁVĚR}

Listina i její výklad jsou úzce navázány na konkrétní předpisy práva EU. Ta její ustanovení, která nemají ekvivalent v mezinárodním právu, zpravidla opakují ustanovení jiných součástí primárního práva EU. Proto se provádění zvláštní kontroly souladu návrhů zákonů s Listinou nejeví jako potenciálně přínosné a efektivní. Logicky to plyne ze skutečnosti, že smyslem přijetí Listiny bylo stanovit meze především veřejné moci vykonávané Unií, tedy orgány a institucemi Unie. Její vztažení na vnitrostátní orgány provádějící právo EU je až druhotné a Listina zde vstupuje do v zásadě fungujícího systému ústavní ochrany a mezinárodních lidskoprávních závazků. Ani v rámci posuzování souladu návrhů zákonů se základními právy jako takovými, bez ohledu na jejich pramen, tak Listina logicky nemůže nabídnout mnoho nového.

Ve vnitrostátním legislativním procesu se proto za současné situace jeví jako nejvhodnější zohledňovat Listinu (a judikaturu Soudního dvora EU) pouze při posuzování souladu návrhů zákonů s právem EU jako takovým, tedy v kontextu jiných ustanovení práva EU. Tomu v zásadě odpovídá i dosavadní praxe př́ípravy vládních návrhů zákonů. Při studiu důvodových zpráv návrhů zákonů a jiných př́pravných dokumentů v rámci vnitrostátního legislativního procesu lze mimo jiné očekávat, že odkazy na Listinu, bu- 
dou-li se vůbec vyskytovat, budou bud' obecné a symbolické, bez reálné interpretační hodnoty, nebo naopak zcela konkrétní, jakožto odkazy na rozsudky Soudního dvora EU vykládající jednotlivá ustanovení práva EU ve světle Listiny.

JUDr. Jan Grinc, Ph.D.

Katedra ústavního práva Právnické fakulty Univerzity Karlovy grinc@prf.cuni.cz 